УДК 001.18:[005+658]:339.9

DOI: https://doi.org/10.37320/2415-3583/15.7

Данько Т.В.

кандидат економічних наук, професор

Національний технічний університет

"Харківський політехнічний інститут»

ORCID: https://orcid.org/0000-0003-1308-826X

Ширясва Н.В.

кандидат технічних наук, доцент

Національний технічний університет

«Харківський політехнічний інститут»

ORCID: https://orcid.org/0000-0002-0837-7238

\title{
КОРПОРАТИВНИЙ ФОРСАЙТ В МЕНЕДЖМЕНТІ МІЖНАРОДНОГО БІЗНЕСУ
}

Питання корпоративного форсайту набувають значну актуальність в управлінні мультинаціональними компаніями. Мета дослідження спрямована на визначення та систематизацію сучасних наукових поглядів щзодо застосування корпоративного форсайту в сфері менеджменту міжнародного бізнесу. До основних результатів дослідження відноситься таксономія цінності застосування корпоративного форсайту за предметними областями дослідження міжнародного бізнесу. Також в статті запропоновано матрицю видів корпоративного форсайту. Вона надає можливість ідентифікувати недостатньо вивчені питання використання корпоративного форсайту в міжнародному бізнесі, до яких, зокрема, належить процес інтернаціоналізації підприємства. $B$ подальшому значної наукової уваги заслуговують питання особливостей корпоративного форсайту в міжнародних компаніях в умовах діджиталізації та четвертої промислової револючії.

Ключові слова: форсайт, корпоративний форсайт, міжнародний бізнес, менеджмент, міжнародний менеджмент, мультинаціональна компанія.

Постановка проблеми. Протягом останніх років спостерігається значне зростання наукового інтересу до проблематики корпоративного форсайту. Переважно, викликано це поширенням думки, що корпоративний форсайт відіграє важливу роль у забезпеченні довгострокової конкурентоспроможності бізнесу в умовах турбулентного зовнішнього середовища [1].

Слід зазначити, що на практиці використання корпоративного форсайту $є$ в першу чергу характерним для успішних мультинаціональних корпорацій (МНК) [2]. Враховуючи, що сучасна теорія міжнародного бізнесу в значній мірі побудована на вивченні діяльності МНК, можна стверджувати, що застосування корпоративного форсайту поступово стає важливою складовою сучасного менеджменту міжнародного бізнесу та інтернаціоналізації компаній [3]. В той же час характер та особливості застосування форсайту в міжнародному бізнесі залишається мало вивченим.

Аналіз останніх досліджень і публікацій. Поняття корпоративного форсайту є відносно новим, хоча й має глибоке коріння. Усталення словосполучення “корпоративний форсайт" припадає на 1990-і роки по мірі того, як деякі автори, такі як, наприклад, П. Баклі та М. Чепмен [4], Е. Хайнс [5], А. Фінк та О. Шлейк [6], починають вживати його для означення систематичної діяльності на рівні підприємств 3 дослідження сценаріїв майбутнього, підкреслюючи його особливості у порівнянні з подібними діями або здатностями на рівні індивіда, науковця або держави. В той же час, корпоративний форсайт можна вважати спадкоємцем довгострокового прогнозування в системі стратегічного менеджменту підприємств [7] та сценарного планування, яке почали використовувати мультинаціональні компанії у 1970-х роках [8].
Принагідно зауважимо, що аналіз публікацій 3 питань форсайту на рівні управління підприємствами демонструє, що поняття корпоративного форсайту часто використовується поряд з поняттям стратегічного форсайту без уточнення характеру зв'язку між ними [8]. Така довільність у використанні терміну стає особливо помітною по мірі звуження предмету дослідження на рівні міжнародних компаній. Слід зазначити, що часто ці поняття використовуються як однозначні.

Серед перших наукових досліджень безпосередньо корпоративного форсайту варто відзначити опитування щодо його стану у 18 обраних підприємствах, яке провів П. Бекер на замовлення Сврокомісії у 2002 році [9], та статтю Ф.Руфа, присвячену кейсу інтеграції корпоративного форсайту у стратегічний процес та інноваційну діяльність на рівні мультинаціональної компанії [10].

До певних аспектів використання форсайту в управлінській діяльності підприємств в різний час зверталися такі українські дослідники як К. Руліцька [11; 12], А. Фалович [13], О. Нагорнова, С. Ожема [14], Т. Данько, Н. Ширяєва [15; 16], Д. Гощинська [17], Е. Мединська [18] та С. Турчіна [19]. Зокрема, на думку С. Дунди та О. Ковтун, форсайт може стати досить ефективним методом стратегічного менеджменту вітчизняних підприємств [20].

В зарубіжній науковій літературі цим питанням приділяється значно більше уваги. Одним 3 провідних дослідників корпоративного форсайту є Р. Рорбек [2; 8; 21-23]. Згідно визначення корпоративного форсайта, запропонованого Р. Рорбеком у співавторстві С. Баттістеллою та I. Хуізінгом, ця діяльність спрямована на створення майбутніх конкурентних переваг шляхом визначення, спостереження та інтерпретації факторів, які призводять до змін, що можуть мати важ- 
ливі наслідки для організацій, а також до започаткування відповідних дій організації [8].

Окремим напрямом досліджень можна виділити проблеми застосування методів форсайту в міжнародних компаніях. Одними 3 перших до цього питання звернулися Ф. Руфф [24], Д. Райд та С. Зиглідопулос [25]. Надалі ця тема набула подальшого розвитку в працях А. Алсана [26], Р. Рорбека зі співавторами [2; 23; 27-29]. Певний інтерес має і дослідження А. Юнера та С. Гьоль Бешер [30]. Як зазначалося вище, в цих працях розглядається як корпоративний форсайт в цілому, так і виділяються його стратегічна та технологічна складові. Особливу увагу взаємозв'язку корпоративного форсайту та стратегічного управління в МНК приділяє А. Березной [31].

Слід зазначити, що на даний момент теоретичне обгрунтування використання корпоративного форсайту в міжнародному бізнесі залишається недостатнім. Серед розглянутих вище праць, лише Д. Райд та С. Зиглідопулос вказують на безпосередній зв'язок свого дослідження 3 теорією міжнародного бізнесу [25]. Також перелічені праці в переважній кількості побудовані на окремих кейсах. Можна виділити тільки дві недавні праці, а саме Р. Рорбека та Я. Шварца [23], а також А. Березного [31], в яких автори вдаються до певних теоретичних узагальнень щодо переваг та особливостей застосування форсайту на корпоративному рівні в МНК.

Таким чином, можна стверджувати, що на сьогоднішній момент на рівні теоретичних узагальнень корпоративний форсайт та міжнародний бізнес існують ніби як в паралельних світах. Хоча на практиці міжнародні компанії застосовують корпоративний форсайт, а дослідники визнають перспективність та актуальність застосування форсайту в менеджменті міжнародного бізнесу, ця діяльність поки що виглядає як експериментування та окремі кейси, які в цілому не вписуються в загальну парадигму міжнародного бізнесу. В той же час, на наш погляд, розв'язання цієї проблеми відкриває нові можливості розвитку сучасної теорії міжнародного бізнесу.

Мета статті полягає в визначенні та систематизації сучасних наукових поглядів на застосування корпоративного форсайту в сфері менеджменту міжнародного бізнесу.

Виклад основного матеріалу. Згідно підходу щодо розвитку наукових засад міжнародного бізнесу, який рекомендують П. Баклі та Д. Лессард, поява нових концепцій $є$ результатом синтезу між спостереженнями за проявами нового явища та усталеними теоретичними поглядами [32]. В нашому випадку таким новим явищем $є$ застосування корпоративного форсайту в міжнародних компаніях, а в якості усталених теоретичних поглядів пропонується розглядати набір типових предметів дослідження міжнародного бізнесу.

Оскільки сучасні наукові знання про міжнародний бізнес динамічно розвиваються, то такий поточний перелік типових предметів дослідження пропонується сформувати на основі аналізу частоти їх згадування у ключових оглядових публікаціях різних років, починаючи з інституалізації міжнародного бізнесу як окремої наукової дисципліни наприкінці 1960-х років [3].

За результатами проведеного аналізу, для подальшого розгляду автори обрали такий перелік типових предметних областей дослідження міжнародного бізнесу, які є похідними від сфер менеджменту міжнародного бізнесу:

- міжнародне бізнес середовище (МБС) [32-36];

- процес інтернаціоналізації компанії (I) [32; 35-39];

- стратегія та організація МНК (CO МНК) [33-35; 39; 40];

- функціональні аспекти міжнародного бізнесу (ФМБ) [33-35, 40];

- міжнародний менеджер (ММ) [32-35; 38].

Для аналізу застосування корпоративного форсайту в міжнародному бізнесі авторами обрано дві категорії: практична цінність, яку отримують компанії від його застосування, та види корпоративного форсайту, які згадуються в наукових дослідженнях з міжнародного бізнесу.

На думку авторів ці дві категорії $є$ основоположними для подальшої систематизації сучасних наукових поглядів щодо здійснення корпоративного форсайту в сфері менеджменту міжнародного бізнесу. Розгляд першої категорії дозволяє визначити, в чому саме полягає необхідність застосування корпоративного форсайту в міжнародному бізнесі та, з рештою, як саме проявляється потреба в ньому в менеджменті міжнародного бізнесу. Що стосується видів корпоративного форсайту, то тут першочергове дослідницьке питання полягає в тому, як саме залежить зміст корпоративного форсайту від предметної області дослідження міжнародного бізнесу.

Зв'язки між практичною цінністю застосування корпоративного форсайту за предметними областями дослідження міжнародного бізнесу представлені в таблиці 1 . За основу переліку проявів практичної цінності взято набір, який розроблено Р. Рорбеком та Я. Шварцом за результатами емпіричного дослідження 77 МНК [23]. Його доповнено на основі висновків Д. Райда та С. Зиглідопулоса щодо застосування корпоративного форсайту при виході МНК на ринок Китаю [25].

Як бачимо, загальна цінність, яку отримує міжнародна компанія від застосування корпоративного форсайту, може бути декомпонованою на складові, які відносяться до окремих аспектів менеджменту міжнародного бізнесу. В подальшому ці особливості повинні враховуватися при здійснення корпоративного форсайту за відповідними предметними областями дослідження міжнародного бізнесу. Аналіз дозволяє прийти до висновку, що природа цієї цінності полягає у здатності міжнародних менеджерів забезпечувати конкурентоспроможність та ефективно досягати поставлені цілі за відповідними зонами відповідальності менеджменту міжнародного бізнесу.

Крім цінності відрізняються і види корпоративного форсайту, які є характерними для різних предметних областей дослідження міжнародного бізнесу (табл. 2).

Таким чином доведено, що застосування корпоративного форсайту притаманне для всіх предметних областей дослідження міжнародного бізнесу та в той же час має певні особливості, які проявляються у відмінностях цінності, яку від цього отримує міжнародне підприємство, та видів корпоративного форсайту, характерних для кожної окремої предметної області дослідження міжнародного бізнесу.

Висновки. Застосування корпоративного форсайту поступово стає важливою складовою сучасного менеджменту міжнародного бізнесу та інтернаціоналі- 


\section{Таблиця 1 - Таксономія цінності застосування корпоративного форсайту за предметними областями дослідження міжнародного бізнесу}

\begin{tabular}{|c|c|c|c|c|c|}
\hline \multirow{2}{*}{ Практична цінність для міжнародного підприємства } & \multicolumn{5}{|c|}{ Напрями досліджень міжнародного бізнесу } \\
\hline & МБС & I & СО МНК & ФБМ & MM \\
\hline Передбачення трендів та змін в міжнародному середовищі & 1 & & 1 & & 1 \\
\hline Впровадження успішних інновацій & & & 1 & 1 & \\
\hline $\begin{array}{l}\text { Підвищення ефективності діалогу щодо загальної стратегії підприємства на } \\
\text { основі спільного розуміння майбутнього }\end{array}$ & & & 1 & & 1 \\
\hline $\begin{array}{l}\text { Підвищення швидкості та ефективності реагування керівної ланки } \\
\text { підприємства на кардинальні зміни зовнішнього середовища }\end{array}$ & & & 1 & & \\
\hline Поліпшення досягнення бізнес-цілей в умовах швидких змін & & & 1 & & \\
\hline Підвищення відкритості персоналу до впровадження змін & & & & & 1 \\
\hline Зниження рівня ризиків в науково-дослідних проектах & & & & 1 & \\
\hline Покращення розуміння майбутніх потреб клієнтів & 1 & & & 1 & \\
\hline Виявлення потенційних клієнтів & 1 & & & 1 & \\
\hline Покращення розуміння ринку & 1 & & & 1 & \\
\hline Виявлення можливостей і загроз щодо портфеля продуктів і технологій & 1 & & 1 & & \\
\hline Підвищення ефективності організаційного навчання & & & & 1 & 1 \\
\hline Управління вартістю бізнесу & & & 1 & 1 & \\
\hline Зменшення ризиків при виході на нові зарубіжні ринки & & 1 & & 1 & \\
\hline $\begin{array}{l}\text { Підвищення ефективності управління ризиками в міжнародній діяльності } \\
\text { підприємства }\end{array}$ & & & & 1 & \\
\hline $\begin{array}{l}\text { Підвищення ефективності міжнародної інвестиційної діяльності } \\
\text { підприємства }\end{array}$ & & & & 1 & \\
\hline
\end{tabular}

Таблиця 2 - Матриця видів корпоративного форсайту за предметними областями дослідження міжнародного бізнесу

\begin{tabular}{|c|c|c|c|c|c|}
\hline \multirow{2}{*}{ Види корпоративного форсайту } & \multicolumn{5}{|c|}{ Предметні області } \\
\hline & МБС & $\mathbf{I}$ & СО МНК & ФМБ & MM \\
\hline Визначення глобальних трендів [23; 31] & 1 & & & & \\
\hline Аналіз майбутнього [26; 29] & 1 & & 1 & & \\
\hline Форсайт політичного середовища [23; 27; 29-31] & 1 & & & & \\
\hline Форсайт технологій [2; 23; 27; 29-31] & 1 & & & & \\
\hline Форсайт економічного середовища $[2 ; 23 ; 30 ; 31]$ & 1 & & & & \\
\hline Виявлення майбутніх глобальних ринків [10; 24; 41] & 1 & & & 1 & \\
\hline Форсайт споживачів [2;23;27;29] & 1 & & & & \\
\hline Конкурентний форсайт [27; 29] & 1 & & & & \\
\hline Стратегічний форсайт [2; 23; 25-29; 42] & & 1 & 1 & & \\
\hline Прогностичне мислення [2; 23; 26; 43] & & & 1 & & 1 \\
\hline Орієнтація на майбутнє [23; 26; 43] & & & 1 & & 1 \\
\hline Візія [2] & & & 1 & & \\
\hline Сценарне планування [44] & & & 1 & & \\
\hline $\begin{array}{l}\text { Розробка сценаріїв для майбутніх продуктів, } \\
\text { послуг та бізнес-процесів }[23 ; 24 ; 30 ; 31]\end{array}$ & & & & 1 & \\
\hline Управління інноваціями [23] & & & & 1 & \\
\hline Операційний форсайт [27] & & & & 1 & \\
\hline Організаційне навчання [23] & & & & & 1 \\
\hline
\end{tabular}

зації компаній. Його використання в першу чергу має цінність для компаній, які орієнтовані на швидке зростання або забезпечення довгострокової конкурентоспроможності. Зокрема, це особливо стосується міжнародних компаній, які застосовують проактивний підхід до менеджменту в умовах діджиталізації та четвертої промислової революції. Також, в подальшому значної наукової уваги заслуговують питання особливостей застосування корпоративного форсайту в міжнародних компаніях, які використовують інноваційні стратегії спрямовані на цілі сталого розвитку.
Цінність, яку отримують міжнародні компанії від корпоративного форсайту, має багато аспектів та носить різнобічний характер, який прямо залежить від того в якій саме сфері або предметній області міжнародного бізнесу він застосований. Виходячи $з$ цього, серед іншого варто спрямувати майбутні дослідження корпоративного форсайту в тому числі і на питання, яким чином менеджери, які стикнулися 3 управлінськими проблемами в тій чи іншій предметній області міжнародного бізнесу, повинні оцінити доречність застосування корпоративного форсайту для розв'язання цих 
викликів. Очевидно, що це дослідницьке питання серед іншого стосується і більш широкої проблеми вивчення щоденних практик ефективного застосування менеджерами інформації щодо зовнішнього ділового середовища при прийнятті управлінських рішень. Потребує подальшого дослідження і уточнення й перелік та особливості типових проблем управління міжнародним бізнесом, які вимагають застосування корпоративного форсайту.

В ході дослідження також виявлено, що для різних предметних областей міжнародного бізнесу характер- ними $є$ різні види корпоративного форсайту. Іншими словами, міжнародна компанія може отримати бажану цінність від корпоративного форсайту, тільки якщо іiі менеджери застосовують той його вид, який є найбільш доречний для умов та обставин відповідної управлінської проблеми в міжнародному бізнесі. Таким чином, на подальшу увагу заслуговує і питання як саме менеджери обирають вид корпоративного форсайту, який $\epsilon$ найбільш адекватним для тої управлінської проблеми міжнародного бізнесу, з якою вони стикнулися.

\section{Список використаних джерел:}

1. Hayward P. Facilitating foresight: where the foresight function is placed in organisations. Foresight. 2004. Vol. 6. № 1. P. 19-30.

2. Benchmarking report: strategic foresight in multinational companies / R. Rohrbeck et al. Rochester. NY : Social Science Research Network, 2009. 38 p.

3. Данько Т.В. Еволюція наукових засад міжнародного бізнесу. Проблеми економіки. 2019. № 3(41). С. $109-115$.

4. Buckley P.J., Chapman M. The perception and measurement of transaction costs. International Business. Springer, 1998. P. 57-86.

5. Hines A. The foresight amphibian in the corporate world. Foresight-The journal of future studies, strategic thinking and policy. 1999. Vol. 1, No. 4. P. 382-384.

6. Fink A., Schlake O. Scenario management - an approach for strategic foresight. Competitive Intelligence Review: Published in Cooperation with the Society of Competitive Intelligence Professionals. 2000. Vol. 11. № 1. P. 37-45.

7. Gordon A. V. 50 years of corporate and organizational foresight: looking back and going forward / A.V. Gordon et.al. $T$ echnological Forecasting and Social Change. 2020. Vol. 154. P. 1-14.

8. Rohrbeck R., Battistella C., Huizingh E. Corporate foresight: an emerging field with a rich tradition. Technological Forecasting and Social Change. 2015. Vol. 101. P. 1-14.

9. Becker P. Corporate foresight in europe. A First Overview, RTK2 Scientific and Technological Foresight, European Commission. 2002.30 p.

10. Ruff F. Corporate foresight: integrating the future business environment into innovation and strategy. International Journal of Technology Management. 2006. Vol. 34. № 3-4. Р. 278-295.

11. Руліцька К.М. Доцільність використання форсайту для прогнозування розвитку вітчизняних аграрних формувань. Вісник НТУ «ХПI». 2013. № 53 (1026). С. 121-125.

12. Руліцька К. Перспективи використання форсайту для прогнозування розвитку вітчизняних аграрних підприємств. Збірник наукових працьь [Буковинського університету]. Економічні науки. 2014. № 10. Р. 88-94.

13. Фалович А. С. Форсайт у забезпеченні економічної безпеки підприємств машинобудування в посткризовий період. Актуальні задачі сучасних технологій : матеріали Міжнародної науково-технічної конференції молодих учених та студентів, м. Тернопіль, 11-12 грудня 2013. Тернопіль, 2013. С. 332-333.

14. Нагорнова О., Ожема С. Форсайт-дослідження в системі стратегічного планування зовнішньоекономічної діяльності господарської системи. Сталий розвиток економіки. 2013. № 4. С. 287-289.

15. Ширяєва Н. В., Данько Т. В. Питання форсайту щодо розвитку високотехнологічних машинобудівних підприємств Харкова. Ефективна економіка. 2015. № 10.

16. Данько Т.В., Ширяєва Н.В. Форсайт та технологічне прогнозування в системі управління високотехнологічним підприємством. Інформаційні технології: наука, техніка, технологія, освіта, здоров'я (МісrоCAD-2015) : наук. вид. : тези доп. 23-ї міжнар. наук.-практ. конф., 20-22 травня 2015 р. : у 4 ч. Ч. 4 / ред. С.І. Сокол. Харків : НТУ "ХПІ", 2015. С. 158.

17. Гощинська Д.Я. Використання форсайт-методу інноваційного розвитку підприємств на ринку інформаційно-комунікаційних технологій. Економіка. Менеджмент. Бізнес. 2015. № 4. С. 85-90.

18. Мединська Е.С. Онтологія корпоративного форсайту. Вісник Нац. техн. ун-mу "ХПI" : зб. наук. пр. темат. вип: Актуальні проблеми управління та фінансово-господарської діяльності підприємства. Харків : НТУ "ХПІ". 2015. № 23 (1132). С. $52-61$.

19. Турчіна С.Г. Форсайт як сучасний метод управління інноваційним розвитком підприємств аграрної сфери економіки. Ефективність функціонування сільськогосподарських підприємств : матеріали V Міжнародної науково-практичної щорічної інтернет-конференції, м. Львів, 23-27 травня 2016 р. Львів : ЛНАУ, 2016.

20. Дунда С.П. Технологія форсайт як інструмент стратегічного менеджменту. Молодий вчений. 2017. № 12(52). С. $612-616$.

21. Rohrbeck R. Corporate foresight: towards a maturity model for the future orientation of a firm. Springer Science \& Business Media. 2010. 240 p.

22. Rohrbeck R., Gemünden H.G. Corporate foresight: its three roles in enhancing the innovation capacity of a firm. Technological Forecasting and Social Change. 2011. Vol. 78. № 2. P. 231-243.

23. Rohrbeck R., Schwarz J.O. The value contribution of strategic foresight: insights from an empirical study of large european companies. Technological Forecasting and Social Change. 2013. Vol. 80. № 8. P. 1593-1606.

24. Ruff F. Society and technology foresight in the context of a multinational company. International Practice in Technology Foresight. 2002. P. 223.

25. Reid D.M., Zyglidopoulos S.C. Causes and consequences of the lack of strategic foresight in the decisions of multinational enterprises to enter China. Futures. 2004. Vol. 36. № 2. P. 237-252.

26. Alsan A. Corporate foresight in emerging markets: action research at a multinational company in turkey. Futures. 2008. Vol. 40. № 1. P. 47-55.

27. Rohrbeck R. Towards a best-practice framework for strategic foresight: building theory from case studies in multinational companies. IAMOT 2008 "Creating and Managing a Knowledge Economy": IAMOT 2008 Proceedings. Dubai, UAE. 2008. P. 15.

28. Rohrbeck R., Gemünden H.G. Strategic foresight in multinational enterprises: building a best-practice framework from case studies. Emerging Methods in R\&D Management Conference. 2008. P. 10-20.

29. Rohrbeck R., Arnold H.M., Heuer J. Strategic foresight in multinational enterprises - a case study on the deutsche telekom laboratories. ISPIM-Asia 2007 conference. New Delhi, India - 9-12 January. 2007. 
30. Atilla Öner M., Göl Beșer S. Assessment of corporate foresight project results: case of a multinational company in turkey. Foresight. 2011. Vol. 13. № 2. P. 49-63.

31. Bereznoy A. Corporate foresight in multinational business strategies. Foresight and STI Governance. 2017. Vol. 11. № 1. P. 9-22.

32. Buckley P.J., Lessard D.R. Regaining the edge for international business research. Journal of International Business Studies. 2005. Vol. 36. № 6. P. 595-599.

33. Wright R.W. Trends in international business research. Journal of International Business Studies. 1970. Vol. 1. № 1. P. $109-123$.

34. Wright R.W., Ricks D.A. Trends in international business research: twenty-five years later. Journal of International Business Studies. 1994. Vol. 25. № 4. P. 687-701.

35. Griffith D.A., Tamer Cavusgil S., Xu S. Emerging themes in international business research. Journal of International Business Studies. 2008. Vol. 39. № 7. P. 1220-1235.

36. Seno-Alday S. International business thought: a 50-year footprint. Journal of International Management. 2010. Vol. 16. № 1. P. 16-31.

37. Glaum M., Oesterle M.-J. 40 years of research on internationalization and firm performance: More questions than answers? Management International Review. Vol. 47. P. 307-317.

38. Rugman A.M., Verbeke A., Nguy Q.T. Fifty years of international business theory and beyond. Management International Review. 2011. Vol. 51. № 6. P. 755-786.

39. Rialp A., Merigó J.M., Cancino C.A., Urbano D. Twenty-five years (1992-2016) of the international business review: a bibliometric overview. International Business Review. 2019. Vol. 28. P. 1-28.

40. Caves R.E. Research on international business: problems and prospects. Journal of International Business Studies. 1998. Vol. 29. № 1. P. 5-19.

41. Mićić P. Future markets-radar: a case study of applied strategic foresight. Technological Forecasting and Social Change. 2010. Vol. 77. № 9. P. 1499-1505.

42. Данько Т.В., Ширяєва Н.В. Стратегічний форсайт в мультинаціонаціональних корпораціях. Формування механізму зміцнення конкурентних позицій національних економічних систем у глобальному, регіональному та локальному вимірах : матеріали IV Міжнародної науково-практичної конференції, 31 березня 2020 року. Тернопіль, 2020. Р. 91-92.

43. Liu Z., Zhu H. Chinese firms' sustainable development - the role of future orientation, environmental commitment, and employee training / Z. Liu, [et al.]. Asia Pacific Journal of Management. 2014. Vol. 31. № 1. P. 195-213.

44. Cairns G., Śliwa M., Wright G. Problematizing international business futures through a 'critical scenario method'. Futures. 2010. Vol. 42. № 9. P. 971-979.

\section{References:}

1. Hayward P. (2004) Facilitating foresight: where the foresight function is placed in organisations. Foresight, vol. 6, no. 1, pp. 19-30.

2. R. Rohrbeck et al. (2009) Benchmarking report: strategic foresight in multinational companies. Rochester, NY: Social Science Research Network.

3. Danko T.V. (2019) Evoliutsiia naukovykh zasad mizhnarodnoho biznesu [The evolution of the scientific foundations of international business]. Problemy ekonomiky, no. 3(41), pp. 109-115.

4. Buckley P.J., Chapman M. (1998) The perception and measurement of transaction costs. International Business. Springer, pp. $57-86$.

5. Hines A. (1999) The foresight amphibian in the corporate world. Foresight-The journal of future studies, strategic thinking and policy, vol. 1, no. 4, pp. 382-384.

6. Fink A., Schlake O. (2000) Scenario management - an approach for strategic foresight. Competitive Intelligence Review: Published in Cooperation with the Society of Competitive Intelligence Professional, vol. 11, no. 1, pp. 37-45.

7. Gordon A.V. (2020) 50 years of corporate and organizational foresight: looking back and going forward / A. V. Gordon et al. Technological Forecasting and Social Change, vol. 154, pp. 1-14.

8. Rohrbeck R., Battistella C. (2015) Huizingh E. Corporate foresight: an emerging field with a rich tradition. Technological Forecasting and Social Change, vol. 101, pp. 1-14.

9. Becker P. (2002) Corporate foresight in Europe. A First Overview, RTK2 Scientific and Technological Foresight, European Commission.

10. Ruff F. (2006) Corporate foresight: integrating the future business environment into innovation and strategy. International Journal of Technology Management, vol. 34, no. 3/4, pp. 278-295.

11. Rulitska K.M. (2013) Dotsilnist vykorystannia forsaitu dlia prohnozuvannia rozvytku vitchyznianykh ahrarnykh formuvan [The expediency of using foresight to predict the development of domestic agricultural formations]. Visnyk NTU «KhPI», no. 53 (1026), pp. 121-125.

12. Rulitska K. (2014) Perspektyvy vykorystannia forsaitu dlia prohnozuvannia rozvytku vitchyznianykh ahrarnykh pidpryiemstv [Prospects for the use of foresight to forecast the development of domestic agricultural enterprises]. Zbirnyk naukovykh prats [Bukovynskoho universytetu]. Ekonomichni nauky, no. 10, pp. 88-94.

13. Falovych A.S. (2013) Forsait u zabezpechenni ekonomichnoi bezpeky pidpryiemstv mashynobuduvannia v postkryzovyi period [Foresight in ensuring the economic security of machine-building enterprises in the post-crisis period]. Aktualni zadachi suchasnykh tekhnolohii: materialy Mizhnarodnoi naukovo-tekhnichnoi konferentsii molodykh uchenykh ta studentiv, m.Ternopil, 11-12 hrudnia 2013, Ternopil, pp. 332-333.

14. Nahornova O., Ozhema S. (2013) Forsait-doslidzhennia v systemi stratehichnoho planuvannia zovnishnoekonomichnoi diialnosti hospodarskoi systemy [Foresight research in the system of strategic planning of foreign economic activity of the economic system]. Stalyi rozvytok ekonomiky, no. 4, pp. 287-289.

15. Shyriaieva N.V., Danko T.V. (2015) Pytannia forsaitu shchodo rozvytku vysokotekhnolohichnykh mashynobudivnykh pidpryiemstv Kharkova [Foresight on the development of high-tech machine-building enterprises in Kharkiv]. Efektyvna ekonomika, no. 10.

16. Danko T.V., Shyriaieva N.V. (2015) Forsait ta tekhnolohichne prohnozuvannia v systemi upravlinnia vysokotekhnolohichnym pidpryiemstvom [Foresight and technological forecasting in the management system of a high-tech enterprise]. Informatsiini tekhnolohii: nauka, tekhnika, tekhnolohiia, osvita, zdorovia (MicroCAD-2015): nauk.vyd.: tezy dop. 23-yi mizhnar. nauk.-prakt. konf., 20-22 travnia 2015 r.: u 4 ch. Ch. 4 / red. Ye.I. Sokol. Kharkiv: NTU "KhPI", pp. 158. 
17. Hoshchynska D.Ya. (2015) Vykorystannia forsait-metodu innovatsiinoho rozvytku pidpryiemstv na rynku informatsiinokomunikatsiinykh tekhnolohii [Using the foresight method of innovative development of enterprises in the market of information and communication technologies]. Ekonomika. Menedzhment. Biznes, no. 4, pp. 85-90.

18. Medynska E.S. (2015) Ontolohiia korporatyvnoho forsaitu [Ontology of corporate foresight]. Visnyk Nats. tekhn. un-tu "KhPI": zb. nauk. pr. temat. vyp.: Aktualni problemy upravlinnia ta finansovo-hospodarskoi diialnosti pidpryiemstva. Kharkiv: NTU "KhPI", no. 23 (1132), pp. 52-61.

19. Turchina S.H. (2016) Forsait yak suchasnyi metod upravlinnia innovatsiinym rozvytkom pidpryiemstv ahrarnoi sfery ekonomiky [Foresight as a modern method of managing the innovative development of enterprises in the agricultural sector of the economy]. Efektyvnist funktsionuvannia silskohospodarskykh pidpryiemstv: materialy V Mizhnarodnoi naukovo-praktychnoi shchorichnoi internet-konferentsii, m. Lviv, 23-27 travnia 2016 r. Lviv: LNAU.

20. Dunda S.P. (2017) Tekhnolohiia forsait yak instrument stratehichnoho menedzhmentu [Foresight technology as a tool of strategic management]. Molodyi vchenyi, no. 12(52), pp. 612-616.

21. Rohrbeck R. (2010) Corporate foresight: towards a maturity model for the future orientation of a firm. Springer Science \& Business Media, 240 p.

22. Rohrbeck R., Gemünden H.G. (2011) Corporate foresight: its three roles in enhancing the innovation capacity of a firm. Technological Forecasting and Social Change, vol. 78, no. 2, pp. 231-243.

23. Rohrbeck R., Schwarz J.O. (2013) The value contribution of strategic foresight: insights from an empirical study of large european companies. Technological Forecasting and Social Change, vol. 80, no. 8, pp. 1593-1606.

24. Ruff F. (2002) Society and technology foresight in the context of a multinational company. International Practice in Technology Foresight, pp. 223.

25. Reid D.M., Zyglidopoulos S.C. (2004) Causes and consequences of the lack of strategic foresight in the decisions of multinational enterprises to enter China. Futures, vol. 36, no. 2, pp. 237-252.

26. Alsan A. (2008) Corporate foresight in emerging markets: action research at a multinational company in turkey. Futures, vol. 40, no. 1, pp. 47-55.

27. Rohrbeck R. (2008) Towards a best-practice framework for strategic foresight: building theory from case studies in multinational companies. IAMOT 2008 "Creating and Managing a Knowledge Economy": IAMOT 2008 Proceedings. Dubai, UAE, pp. 15.

28. Rohrbeck R., Gemünden H.G. (2008) Strategic foresight in multinational enterprises: building a best-practice framework from case studies. Emerging Methods in R\&D Management Conference, pp. 10-20.

29. Rohrbeck R., Arnold H.M., Heuer J. (2007) Strategic foresight in multinational enterprises-a case study on the deutsche telekom laboratories. ISPIM-Asia 2007 conference. New Delhi, India - 9-12 January.

30. Atilla Öner M., Göl Beşer S. (2011) Assessment of corporate foresight project results: case of a multinational company in turkey. Foresight, vol. 13, no. 2, pp. 49-63.

31. Bereznoy A. (2017) Corporate foresight in multinational business strategies. Foresight and STI Governance, vol. 11, no. 1, pp. 9-22.

32. Buckley P.J., Lessard D.R. (2005) Regaining the edge for international business research. Journal of International Business Studies, vol. 36, no 6, pp. 595-599.

33. Wright R. W. (1970) Trends in international business research. Journal of International Business Studies, vol. 1, no 1, pp. 109-123.

34. Wright R. W., Ricks D. A. (1994) Trends in international business research: twenty-five years later. Journal of International Business Studies, vol. 25, no. 4, pp. 687-701.

35. Griffith D.A., Tamer Cavusgil S., Xu S. (2008) Emerging themes in international business research. Journal of International Business Studies, vol. 39, no. 7, pp. 1220-1235.

36. Seno-Alday S. (2010) International business thought: a 50-year footprint. Journal of International Management, vol. 16, no. 1 , pp. 16-31.

37. Glaum M., Oesterle M.-J. (2007) 40 years of research on internationalization and firm performance: More questions than answers? Management International Review, vol. 47, pp. 307-317.

38. Rugman A.M., Verbeke A., Nguy Q.T. (2011) Fifty years of international business theory and beyond. Management International Review, vol. 51, no. 6, pp. 755-786.

39. Rialp A., Merigó J.M., Cancino C.A., Urbano D. (2019) Twenty-five years (1992-2016) of the international business review: a bibliometric overview. International Business Review, vol. 28, pp. 1-28.

40. Caves R.E. (1998) Research on international business: problems and prospects. Journal of International Business Studies, vol. 29, no.1, pp. 5-19.

41. Mićić P. (2010) Future markets-radar: a case study of applied strategic foresight. Technological Forecasting and Social Change, vol. 77, no. 9, pp. 1499-1505.

42. Danko T.V., Shyriaieva N.V. (2020) Stratehichnyi forsait v multynatsionatsionalnykh korporatsiiakh [Strategic Foresight in Multinational Companies]. Formuvannia mekhanizmu zmitsnennia konkurentnykh pozytsii natsionalnykh ekonomichnykh system u hlobalnomu, rehionalnomu ta lokalnomu vymirakh: materialy IV Mizhnarodnoi naukovo-praktychnoi konferentsii, 31 bereznia 2020 roku. Ternopil, pp. 91-92.

43. Liu Z., Zhu H. [et al.] (2014) Chinese firms' sustainable development - the role of future orientation, environmental commitment, and employee training, Asia Pacific Journal of Management, vol. 31, no. 1, pp. 195-213.

44. Cairns G., Sliwa M., Wright G. (2010) Problematizing international business futures through a 'critical scenario method'. Futures, vol. 42, no. 9, pp. 971-979. 
Danko Taras, Shyriaieva Natalia

National Technical University

"Kharkiv Polytechnic Institute"

\section{CORPORATE FORESIGHT IN INTERNATIONAL BUSINESS MANAGEMENT}

The analysis of recent studies reveals that the cases of corporate foresight application in the management of multinational companies are becoming increasingly frequent. At the same time, corporate foresight remains poorly integrated in the general theory of international business management. Thus, the aim of the study is to identify and systematize contemporary scientific views on the application of corporate foresight in the field of international business management. The paper contains the analysis of the value and types of corporate foresight in correspondence to the list of typical subject areas of international business studies. The main results of the research include the corporate foresight value taxonomy for the subject areas of international business studies, which is comprehensive and allows further application of performance measurement tools to corporate foresight implementation in different areas of international management in companies. The article also proposes a matrix of corporate foresight types by subject areas of international business studies. It allows to determine, depending on the specified managerial problem of the company's international operations, the most appropriate type of corporate foresight and to identify insufficiently studied issues of corporate foresight in international business, which include, in particular, the process of internationalization. In the future, the issues of corporate foresight in international companies that apply a proactive approach to management in the context of digitalization and the fourth industrial revolution, as well as the development of innovative strategies aimed at sustainable development deserve considerable scientific attention. The list and distinctions of typical problems of international business management that require the use of corporate foresight also need further clarification. Also, future research on corporate foresight should focus on how managers dealing with managerial issues in a particular area of international business should assess the appropriateness of using corporate foresight to address these challenges and choose the type of corporate foresight, which is the most adequate for it.

Key words: foresight, corporate foresight, international business, management, international management, multinational company.

JEL classification: F23, M16 